\title{
Wildlife reserves in the USSR
}

\author{
Kathleen Braden
}

The reserve system in the USSR is complex; more than 11.4 million ha of land are involved in several categories, which afford wildlife different degrees of protection. At least $\mathbf{4 0}$ major new reserves are planned for the near future, but Soviet conservationists have to face demands for agricultural land, poaching, increasing pressure from tourism and organizational problems. In 1984 the author visited the USSR to study the scientific uses of the country's reserves. It was Dr Braden's third research trip to the USSR; as Vice-President of the International Snow Leopard Trust she has been involved in discussions there about the captive-breeding and exchange of snow leopards between the USA and the USSR.

Surprisingly little is known to Westerners about the Soviet system of flora and fauna conservation. The Red Book of the USSR, published by the USSR Ministry of Agriculture (Glavpriroda, 1978), lists as endangered 62 species of mammals, 63 species of birds, 29 species of amphibians and reptiles, and approximately 528 plants. The 1985 Red Book (Glavpriroda, 1985) lists, as rare or endangered, 94 species of mammals, 80 species of birds, and 46 species of amphibians and reptiles. However, Soviet scientists have also made the classification schemes more complex, increasing the number of categories from two in 1978 to five in 1985 . The categories show increasing states of endangerment, from the first category-immediately threatened with extinction, to the fifth-not immediately threatened, but meriting protection. Many of the 15 union republics in the USSR publish regional Red Books, and endangered species are accorded protection under federal or Wildlife reserves in the USSR local laws.

In addition to protection by statute, endangered species are defended through the establishment of reserves (Bannikov, 1977). Reserves encompass more than 11.4 million ha, or 0.7 per cent of the USSR, equivalent to an area the size of Scotland, Wales and Northern Ireland combined.

One of the difficulties in interpreting the reserve system of the USSR is the fact that the actual number of reserves varies, depending on the source and definition. Even the Soviet experts I consulted during my 1984 research trip were not in agreement about the inventory because the USSR is in an aggressive period of reservebuilding, and many reserves are in the planning stages. Also, the estimate of land area in reserves depends on criteria. If green zones, a kind of forest reserve that prohibits hunting, are included. the total doubles to approximately 24 million ha. Further additions to the estimate may derive from local hunting reserves and buffer zones around reserves (Lopyrev et al. 1979).

Following Pryde (1977) and Fischer (1981), reserves will be defined here to include six types: zapovedniki (state reserves), national parks, biosphere reserves, national hunting reserves, monuments of nature, and zakazniki (short-term reserves). Only the first four enter into the 11.4 million ha estimate of reserved lands.

\section{Types of reserve}

The mainstay of the reserve system is the zapovedniki or state reserve, but in recent years the USSR has become more flexible in creating new categories of special land either to answer the increasing demands from outdoor enthusiasts or

165 
to participate in the United Nation's 'Man and the Biosphere' programme. The regional distribution of reserves in 1984 is shown in Table 1 . The largest new reserves, of more than 100,000 ha, are concentrated in the northern and eastern regions of the USSR (Pryde, 1977).

\section{Zapovedniki}

These form the principal category of reserved lands, totalling approximately 10.7 million ha in 130 reserves. An additional $20-30$ zapovedniki may be created by the year 2000 , bringing under protection another 5 million ha (Fischer, 1981). Soviet geographers projected a growth to 16.9 million ha by the end of 1985 (Isakov and Krinitskiy, 1983). The largest zapovedniki are in the Asian USSR: Taymyr in north-central Siberia (1.35 million ha), Kronotskiy on the Kamchatka peninsula $(964,000 \mathrm{ha})$, Altay bordering western Mongolia (864,000 ha), and Wrangel Island in the Artic's Chukchi Sea (796,000 ha) (Noskova, 1981). On the other hand, twelve zapovedniki are each less than 1500 ha, and reserves in the western USSR tend to be under $30,000 \mathrm{ha}$.

Most, but not all, of the zapovedniki are managed by the Central Laboratory for the Conservation of Nature of the USSR Ministry of Agriculture. The reserves exist both to protect endangered flora and fauna and to serve as outdoor laboratories for field studies; most have a permanent scientific staff, and host visiting Soviet and, occasionally, foreign scientists.

\section{National parks}

The creation of national parks was allowed by statute in the USSR as far back as 1921, but it was not until the 1960s that the first national parks were established in each of the three Baltic Union republics. This category differs from zapovedniki in that tourism is allowed, and the parks, many along lakeshores, are designated for recreation as well as nature protection. A determination of the actual date of creation of a national park is difficult; for example, Fischer lists the Ala-Archa

Table 1. Distribution of major categories of USSR reserved land by natural zones. 1984

\begin{tabular}{|c|c|c|c|c|c|c|}
\hline Natural zones* & $\begin{array}{l}\text { Zapovedniki } \\
\text { (including those } \\
\text { designated as } \\
\text { biosphere reserves) }\end{array}$ & $\begin{array}{l}\text { Existing } \\
\text { biosphere } \\
\text { reserves }\end{array}$ & $\begin{array}{l}\text { Biosphere } \\
\text { reserves } \\
\text { immediately } \\
\text { planned or } \\
\text { under formation }\end{array}$ & $\begin{array}{l}\text { Existing } \\
\text { national } \\
\text { parks }\end{array}$ & $\begin{array}{l}\text { National } \\
\text { parks } \\
\text { under } \\
\text { formation }\end{array}$ & $\begin{array}{l}\text { Game } \\
\text { reserves }\end{array}$ \\
\hline \multicolumn{7}{|l|}{ European USSR } \\
\hline Taiga & 7 & - & - & 1 & - & - \\
\hline Deciduous and mixed forest & 32 & 2 & 2 & 3 & - & 5 \\
\hline Forest steppe and steppe & 18 & 1 & 3 & - & - & 2 \\
\hline Subtropic & 5 & - & - & - & - & - \\
\hline Mountain & 13 & 1 & - & 2 & 2 & 1 \\
\hline Desert. semi-desert & 4 & 1 & - & 一 & - & - \\
\hline Total European & 79 & 5 & 5 & 6 & 2 & 8 \\
\hline \multicolumn{7}{|l|}{ Asiatic USSR } \\
\hline Arctic & 3 & - & - & - & - & - \\
\hline Taiga & 8 & 1 & - & - & 2 & - \\
\hline Deciduous and mixed forest & 8 & - & - & - & - & - \\
\hline Forest steppe and steppe & 3 & - & - & - & - & - \\
\hline Mountain & 12 & 1 & 1 & 1 & 2 & - \\
\hline Desert. semi-desert & 16 & 1 & - & - & - & 一 \\
\hline Total Asiatic & 50 & 3 & 1 & 1 & 4 & - \\
\hline Total USSR & 129 & 8 & 6 & 7 & 6 & 8 \\
\hline
\end{tabular}

Sources: Fischer. 1981. pp. 500-522. Interviews with Yu. A. Isakov and Evgeniy Yasniy. Institute of Geography. USSR Academy of Sciences, Moscow. October. 1984

*After Fischer, 1981. 
park in Kirgizia as opened in 1977 , but a conversation with geographers at the Academy of Sciences in Moscow revealed that although the park had a director in 1984, it probably existed only on paper even at this time. Existing national parks, as noted on the map, total approximately 0.4-0.5 million ha (Fischer, 1981; Krasnitskiy, 1983).

\section{Biosphere reserves}

The USSR served as host for a major 1983 'Man and Biosphere' international conference in Minsk, and with the addition of the Astrakhan reserve in 1984, brought the number of USSR reserves under the UNESCO programme to eight. Six more are likely to be accepted in the near future, with 10-15 more total projected (Isakov and Krinitskiy, 1983). These biosphere reserves are zapovedniki that have been accorded special international status as representatives of major ecosystem types. Ecosystemzones of the USSR yet to be brought into the system include tundra, taiga, and subtropics.

\section{National hunting reserves}

Hunting has traditionally been an important outdoor activity in Russia, and 273 species of mammals and birds are designated as game animals (Vorontsov and Kharitonova, 1977). Hunting societies, numbering more than 1 million members, are subject to the agencies that administer reserved lands. Seven national hunting reserves, and many smaller ones at the Union republic level, administered under local jurisdiction, are found in the USSR. Lopyrev lists almost 909 million ha as available for hunting land in the Russian Union Republic alone (Lopyrev et al., 1979), much of it administered by Glavokhota, the main administration for game management and nature reserves of the RSFSR. Rangers are supposed to control poaching, and hunting is limited only to a level that would not deplete stocks; however, complaints about poachers often appear in the Soviet press.

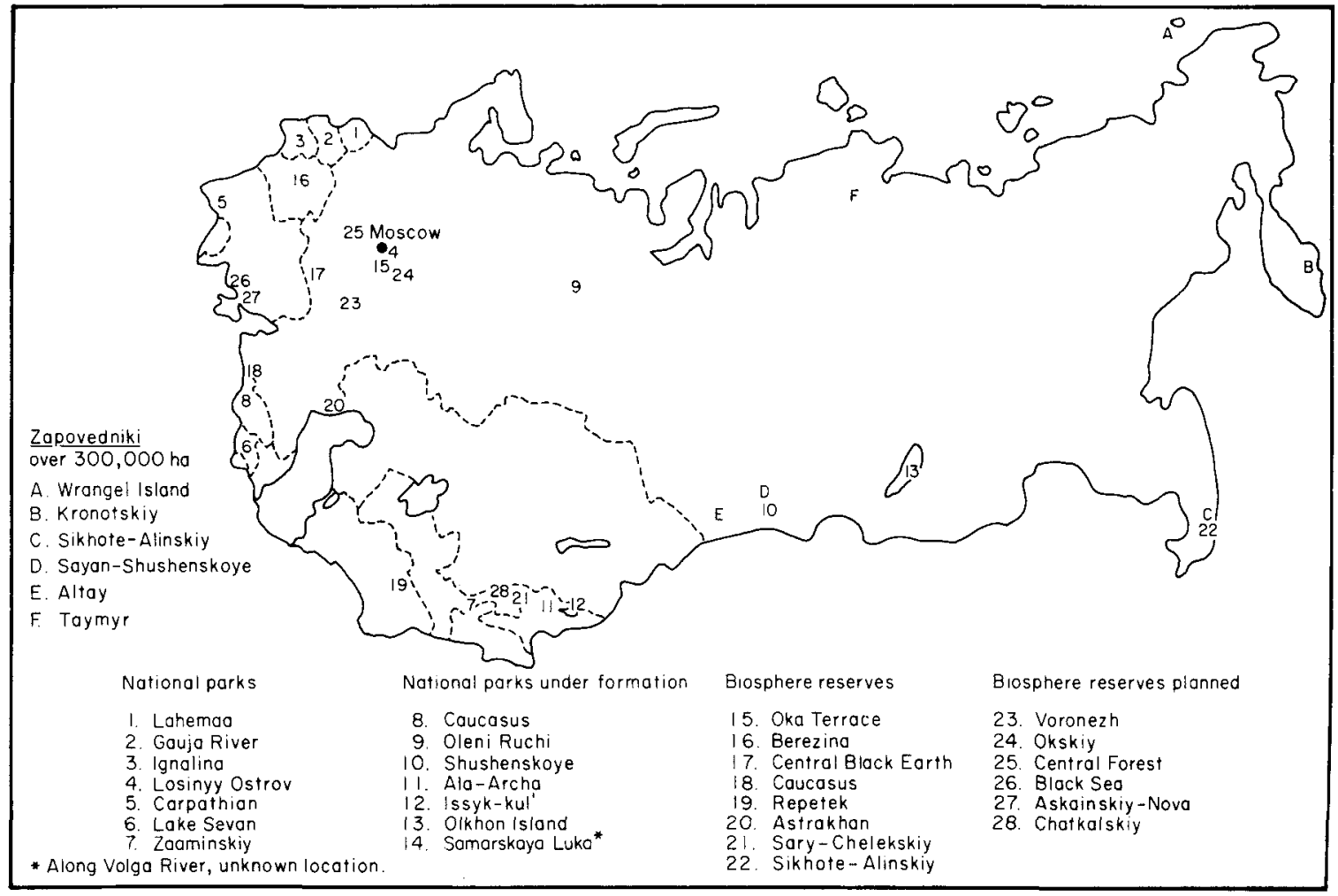

Figure 1. National parks, biosphere reserves, and largest zapovedniki, of the USSR. 1984. 


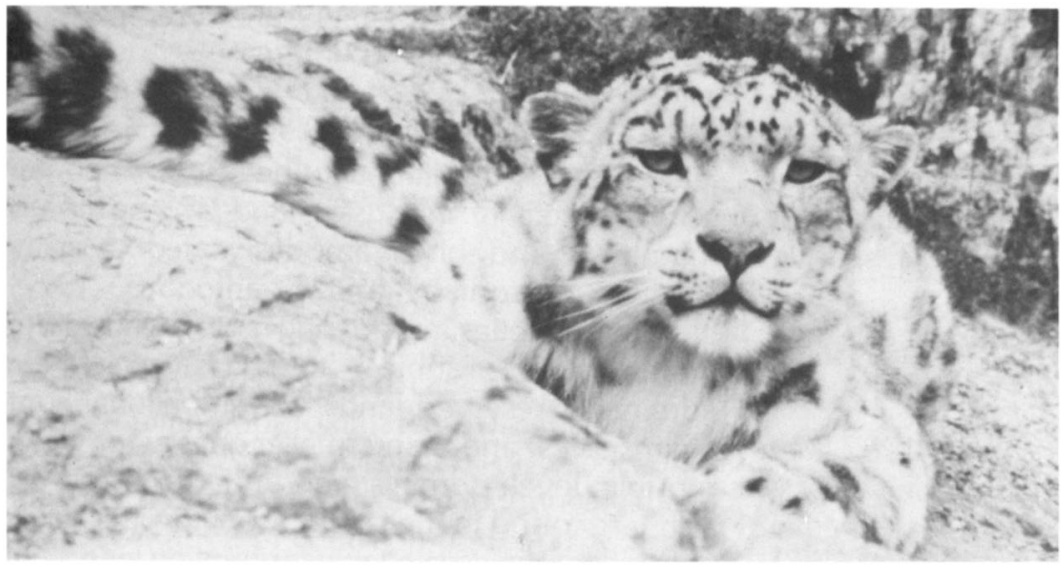

\section{Monuments of nature}

This type of reserved land is limited in size, with small zones outlined around individual natural features, such as geological oddities or unusually old trees. As of 1978, 5523 monuments of nature (40 per cent of which were botanical items) were listed for the Russian Union Republic alone under the Central Soviet of the All-Russian Society of Nature Protection (Reymers and Shtilmark, 1978).

\section{Zakazniki (short-term reserves)}

Zakazniki are limited temporally to allow certain species of flora and fauna to replenish themselves within a specified time period. Under laws established in 1960, exploitation is prohibited during the period unless it does not interfere with the goal of the zakaznik (Reymers and Shtil'mark, 1978). More than 1000 zakazniki existed in 1980 in the USSR, totalling an additional 25 million ha of reserved land (Fischer, 1981).

\section{Management challenges}

While the complexity of the wildlife reserve system in the USSR allows for flexibility in protection methods, it also complicates management tasks. Decision-making responsibility exists in overlapping and often confusing layers. For example, while most zapovedniki are administered by Glaupriroda (the main administration for nature conservation, reserves, forests, and game management) under the Ministry of Agriculture, almost half of the Russian Union 168
Left: The snow leopard is one of the rare mammals protected on the Alma-Atinskiy zapovednik (photographed at Helsinki Zoo).

Right: Sign at edge of a Kazakh zakaznik warning visitors not to cut wood, leave rubbish, or cause fires: 'Remember that all living things take years to create, but. once disturbed. can perish in an instant'.

Below: The Zailiyskiy Alatau near Alma-Ata in the Kazakh Union Republic, in the vicinity of the AlmaAtinskiy zapovednik (Kathleen Braden).

Republic reserves are the responsibility of Glavokhota, and the Zavidovo reserve in the western USSR is managed by the USSR Ministry of Defence (Fischer, 1981). Final approval of reserve creation is given by Gosplan, the State Planning Committee for the Economy, and the long-term stability of reserves is uncertain, given the Soviet past record of reserve abolition. Krasnitskiy lists 128 zapovedniki, covering 12.5

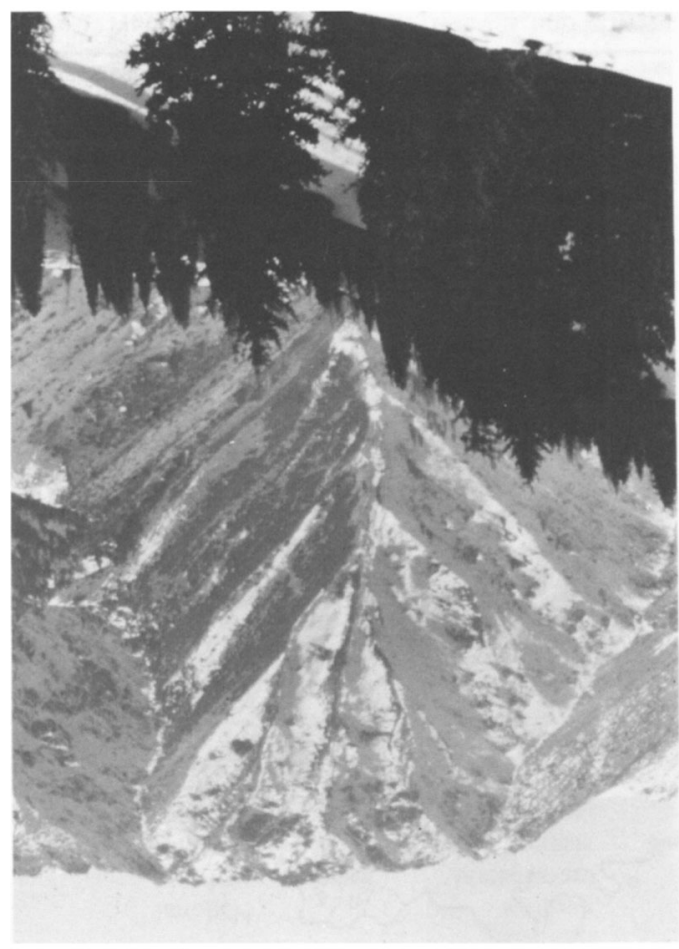

Oryx Vol 20 No 3. July 1986 


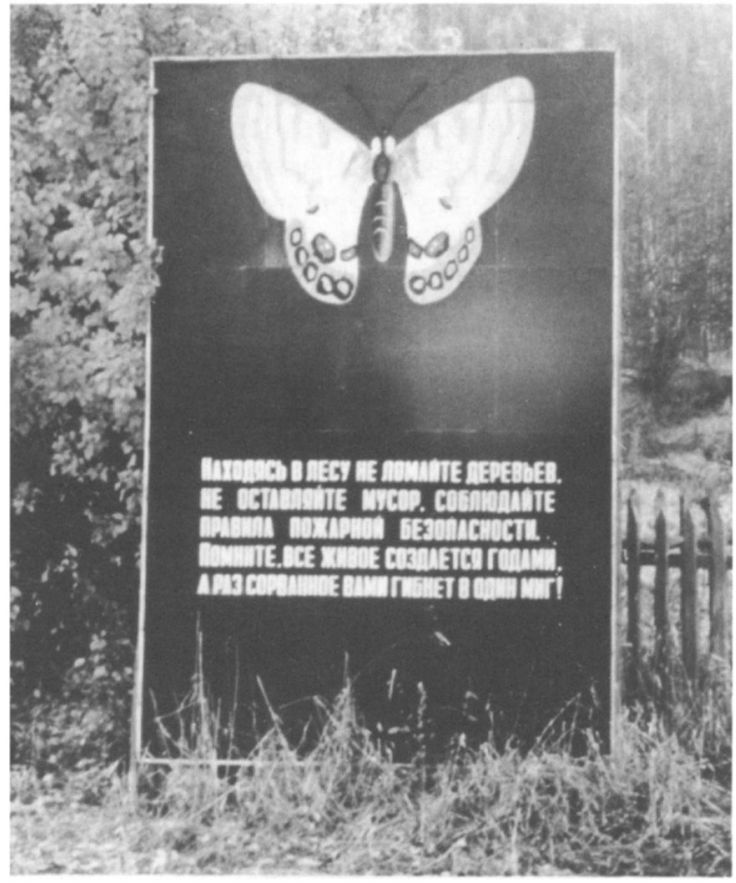

million ha, as of 1950 ; by 1953 a low point of less than 1.4 million ha of reserved land had been reached after 89 zapovedniki were abolished (Krasnitskiy, 1983). Since 1957 the number of zapovedniki has steadily grown again, but arguments over withdrawing land from agricultural or logging use continue.

A second challenge to management concerns the administration of scientific research on nature reserves. The national and union republic academies of science oversee most of the activities in this sphere, but many other local and national agencies also play a role, and each zapovednik is designed to have its own science staff. To overcome confusion over responsibility and to develop a comprehensive plan for zapovednik research, the USSR Academy of Sciences has created a new group under the direction of V. E. Sokolov of the Severtsov Institute of Evolutionary Ecology and Animal Morphology in Moscow. This group will serve as an interdepartmental commission to oversee scientific work on all reserves (interview with $\mathrm{Yu}$. A. Isakov, Institute of Geography, Moscow, October 1984).

Organizational complexities, competition from Wildlife reserves in the USSR agricultural land uses, prevention of poaching, and increasing pressure from tourist demands will all continue to make the work of Soviet conservationists a formidable task. Future challenges will include the needed extension of the biosphere reserve programme into all major Soviet biotypes and realization of at least 40 new projected zapovedniki throughout the USSR. Westerners might appreciate, however, that the conservation ethic is bearing fruit in the USSR despite challenges common to all industrialized societies.

\section{Acknowledgment}

The author acknowledges the support of the International Research and Exchanges Board in New York.

\section{References}

Bannikov. A.G. 1977. Zapovedniki Sovetskogo Soyuza (Reserves of the Soviet Union). Lesnaya promyshlennost'. Moscow.

Fischer, D. 1981. Nature Reserves of the Soviet Union: an inventory. Soviet Geography. $22(8), 510-522$.

Glavpriroda. MSKhSSSR. 1978. Krasnaya kniga SSSR (The Red Book of the USSR). Lesnaya promyshlennost'. Moscow.

Glavpriroda, MSKhSSSR. 1985. Krasnaya kniga SSSR (The Red Book of the USSR). Lesnaya promyshlennost'. Moscow.

Isakov Yu. A. and Krinitskiy. V.V. 1983. Sistema okhranyayemykh prirodnykh territoriy Sovetskogo Soyuza i perspektivy yeye razvitiya (The System of Protected Natural Territories of the Soviet Union and Perspectives for Its Development). In USSR International Congress on Biosphere Reserves. Protected Natural Areas of the USSR. GKNT, Moscow, 27.

Krasnitskiy. A.M. 1983. Problemy zapovednogo dela (Problems of Reserve Affairs). Lesnaya promyshlennost'. Moscow.

Lopyrev, B., Ivashchenko, B., Shtilmark. F., Zykov, K. and Shurupov. I. 1979. Okhranyayemyye territorii i okhotnich"i khozyastva (RSFR (Hunting Territory and Hunting in the RSFSR). Okhota i okhotnich ye khozyaystovo, 3, 12-15.

Noskova, N.K., ed. 1981. Geograficheskoye razmeshchenive zapovednikov $v$ RSFSR i organizatsiya ikh deyatel'nosti (The Geographic Distribution of Reserves in the RSFSR and Organization of Their Activities). Glavokhota. Moscow.

Pryde, P. 1977. Recent Trends in Preserved Natural Areas in the USSR. Environmental Conservation. 4(3), 173-177.

Reymers, N.F. and Shtil'mark. F.R. 1978. Osobo okhranyayemyye prirodnyye territorii (Specially Protected Natural Territories). Mysl'. Moscow.

Vorontsov, A.I. and Kharitonova N.Z. 1977. Okhrana prirody (Protection of Nature). Lesnaya promyshlennost'. Moscow.

Kathleen E. Braden. Seattle Pacific University. Seattle. WA 98119. USA.

169 